\title{
Efficacy of Certain Insecticides on Leaf-Miner Liriomyza Trifolii (Burgess) (Diptera:Agromyzidae)Infesting Green Bean (Phaseolus Vulgaris L.)and Its Parasitoid Digiyphus Isaea (Hymenoptera: Eulophidae)at Alexandria, Egypt
}

\author{
Evleen G. Ibrahim, Mona, E. Abd El-Latif and A.S.T. Barakat ${ }^{1}$
}

\begin{abstract}
Five insecticides named; Tregard, Nasr sedool, Reldan, Selecron and Evisect were evaluated against bean fly Liriomyza trifolii and its parasitoid Diglyphus isaea in the two successive seasons 2006 and 2007. Three different criteria were used in evaluating the degree of infestation.

The results counted that either initial reduction percentage (48 hrs. after application) or mean percentage residual, (5,7,10 and 15 days after application) reduction for living larvae, mines and parasitoid/40 leaflets.

Results showed that the insecticide Selecron was the most potent chemical used against bean fly. Also, insecticide Reldan gave satisfactory results with moderate effect on parasitoid while Evisect was the lowest effective one on bean fly during two seasons and had no detrimental effects on parasitoid.
\end{abstract}

This proves that combination of Reldan (I.G.R.) with Evisect may fit well for IPM programes.

\section{INTRODUCTION}

Bean, Phasealus vulgaris is an important crop consumed by the majority of Egyptian people.

Leaf-miner flies of genus liriomyza (Mink) are among the most injurious dipterous insects attacking vegetable and horticultural crops (Jones et al., 1986 and Parrella et al., 1987).

Although the leaf-miner flies are considered to be secondary pests on tomatoes (Johnson et al., 1980), up to $90 \%$ of the foliage may be lost if the population increased (Schuster, 1978).

Field observation showed that broad bean when grown in newly reclaimed regions, is subjected to attack by L. Trifolii (Ahmed et al., 1994).

Chemical control of the bean fly, Liriomyza trifolii the most serious pest of the faba bean, has long been tackled (El-Nahal and Assem, 1970).

In particular, several reports of insecticidal resistance in this respect were published and documented (Alverson and Gorsuch, 1982).

The ectoparasite Diglyphus spp. (Hymenoptera; Eulophidae) constitutes one of the most important group of parasites that attack Liriomyza app. (Perrella and
Robb 1985). However, once insecticide is applied any balance that has existed between parasitoid and host is disrupted and a continual insecticide control program usually becomes necessary (Hannou et al., 2000).

In the present study was conducted to evaluate the effects of certain insecticides against bean fly $L$. trifolii and its parasitoid D. isaea in the two successive seasons 2006 and 2007.

\section{MATERIALS AND METHODS}

The present study was carried out at the experimental farm of El-Sabaheia Research Station Alexandria Governorate during the Nili seasons of 2006 and 2007.

Bean seeds Phaseolus vulgaris variety Bronco green were planted in August of both seasons, in an area of one feddan. All common cultural practices and fertilizers were followed.

Five insecticides were tested at the recommended rate by the Ministry of Agriculture as shown in Table (1).

The experiment consisted of six treatments including the untreated control, arranged in a randomized complete block design (RCBD). With 4 replicates for each treatment, each replicate was $14 \mathrm{X} 10 \mathrm{~m}^{2}$. A knapsack sprayer was used in applying the insecticides, which diluted with water to 400 liters/feddan as foliar treatment.

The inspection of infestation was carried out just before spraying and at 2 (initial effect), 5, 7, 10 and 15 days (residual effect) intervals, after spraying of each treatment for both seasons.

To evaluate the efficacy of insecticides on L. trifolii and its parasitoid Diglyphus isaea. (Hymenoptera, Eulophidae) in bean fields, samples of 10 leaves of green bean were taken at random from the inner rows of each replicate in polyethylene bags then transmitted to the laboratory where binocular microscope was used to counting the total number of mines, living larvae and numbers of parasitoids (larvae).

The reduction percentages in the populations of the studied insects were estimation using Henderson and

\footnotetext{
${ }^{1}$ Plant Protection Research Institute, Agricultural Research Center, Sabahia, Alexandria

Received May5, 2008, Accepted May22, 2008
} 
Table1. The insecticides used against leaf minor Liriomyza trifolii and its parasitoid

\begin{tabular}{|c|c|c|c|}
\hline Common name & Rate/feddan (L.) & Pesticide group & Producing company \\
\hline $\begin{array}{l}\text { (1)Tregard 10\% sl } \\
\text { (Cyromazine). }\end{array}$ & $0.850 \mathrm{~L}$. & Insect Growth regulator & Syngenta Co. \\
\hline $\begin{array}{l}\text { (2) Nasr sedool } 60 \% \text { Ec } \\
\text { (Diazinon) }\end{array}$ & $1.00 \mathrm{~L}$. & Organo-phosphorus & El-Nasr Co. for chemical \\
\hline $\begin{array}{l}\text { (3) Reldan 50\% Ec } \\
\text { (Chlorpyriphos methyl) }\end{array}$ & $1.00 \mathrm{~L}$. & Organo-phosphorus & Agreen caerv Co. \\
\hline $\begin{array}{l}\text { (4) Selecron } 72 \% \text { Ec } \\
\text { (Profenofos) }\end{array}$ & $0.750 \mathrm{~L}$. & Organo- phosphorus & Syngenta Co. \\
\hline $\begin{array}{l}\text { (5) Evisect } 50 \% \text { sp } \\
\text { (Thiocyclam hydrogen oxylate) }\end{array}$ & $0.500 \mathrm{k.g}$. & Nereistoxin & N.M. Agro. Co. \\
\hline
\end{tabular}

Tilton (1955) equation. Data were also statistically analyzed with analysis of variance (ANOVA), means were compared by L.S.D. test at 0.05 level (steel and Torrie, 1980).

\section{RESULTS AND DISCUSSIONS}

\section{Efficiency of insecticides against larvae of $L$. trifolii:}

The reduction percentages of $L$. Trifolii larvae after application of the tested compounds during the Nile seasons of 2006 and 2007 were presented in Table (2).

The percentage initial of reduction ranged between $57.0 \%$ and $99.3 \%$ in 2006 . While, it ranged from $49.5 \%$ to $98.8 \%$ in 2007 season. All tested compounds redused the number of L. Trifolii larvae, but with different degrees depending on the chemical group.

In 2006 it is clear that Selecron and Reldan were the most effective compounds against $L$. Trifolii larvae in $99.3 \%$ and $97.7 \%$ initial kill, respectively after 2 days after treatment and significantly differed from the others. Tregard came on the second order $(67.5 \%$ initial kill) followed by. Nasr sedool recorded $61.9 \%$ and then Eviseet (57.0\% initial kill), with significant difference. Taking the mean of residual effect (mean of \% reduction at 5,7,10 and 15 days post treatment) into consideration, the tested compounds could be arranged as follow, Tregard (90.2), Selecron (89.15\%) Nasr sedool (84.1\%) and Reldan $(83.75 \%)$ with non significant differences while Evisect gave the lowest activity $68.77 \%$ and significantly differed comparing with all other treatments.

During 2007 Nili season, the order of insecticides efficacy obtained were not differed from the previous trend in the season of 2006. Selecron was still the most potent chemical, whereas Evisect was the lowest effective one. Application of Selecron (Profenofos) at the recommended rate $(0.750 \mathrm{~L}$./fed.) gave the highest initial kill $98.8 \%$ with a significant difference from other pesticides, followed by Reldan $93.4 \%$, Tregard $66.4 \%$, Nasr sedool 59.8\%. Evisect was still the least effective one (49.6\%). Concerning to the mean of residual reduction percentages, the tested compounds could be arranged as Selecron, Tregard, Nasr sedool, Reldan and Evisect were not significantly different $(87.17 \%$, $84.27 \%, 83.65 \%, 82.87 \%$ and $71.37 \%$, respectively).

However, it could be concluded that the efficiency of the tested insecticides based on the average number of living larvae of the two seasons was evidence that Selecron (profenofos) gave high efficiency (the most toxic to L. Trifolii larvae) while Evisect caused the lowest efficiency.

Table (3) represents the reduction percentages of mine numbers caused by Liriomyza trifolii per 40 leaflets after insecticidal applications during 2006 and 2007 seasons.

Results in 2007 showed that initial and mean of residual reduction percentages of mines in all treatments was relatively higher than that in 2006 season. There were significant differences between initial reduction percentages in all the tested insecticides, (Table 3).

These results were agree with the previous findings of El-Haemaesy et al. (1974) which showed that some insecticides such as Anthio, Nexion and sumithion were effective in reducing the number of mines and killing $L$. Trifolii larvae infesting broad bean plants.

As conclusion the greatly decreasing of living larvae after insecticide applications indicated that counting the surviving larvae may be more accurate than counting the infested leaflets merely or counting the mines which contain dead larvae and/or empty mines besides the living larvae.

Abdalla et al. (1992) also mentioned that evaluation of insecticides against Phytomyza atricornis should depend on estimation of the infested leaves in the field and also include the determination of survival larvae in the laboratory. 


\section{Efficiency of insecticides against parasitoid D. isaea}

Obtained data from Nili seasons of 2006 and 2007 presented in Table (4). In 2006, tested compounds reduced the ecto parasite Diglyphus spp. of leaf miner $L$. Trifolii. The initial kill of Selecrone was the highest $(63.0 \%)$ but Evisect was the lowest percentage of reduction $7.1 \%$ while the remain compoundes. Tregard, Nasr sedool and Reldan gave significant differences $25 \%, 37.5 \%$ and $42.9 \%$ initial reduction, resp. Data of the mean percentages of parasite reduction after 15 days post treatment showed that, Selecron gave also the highest mean percentage of reduction $(75.5 \%)$ followed by Tregard $(61.9 \%)$ which slightly diflered from Nasr sedool and Reldan. But the difference between means percentages of reduction of Nasr sedool and Reldan were insignificant.

Evisect gave the lowest mean percentage of reduction $26.7 \%$ with a significant differences comparing with all remained tested compounds.

In 2007 season, results showed that, Selecron (Profenofos), also was the most effective pesticide against parasite, whereas its initial reduction percentage was relatively higher than other tested compounds with significant differences. They were $56.0 \%, 50.6 \%$, $48.0 \%, 33.0 \%$ and $20.3 \%$ respectively. The mean reduction percentages were $78.97 \%, 61.22 \%, 56.15 \%$, $53.4 \%$ and $31.51 \%$ for Selecron, Tregard, Reldam, Nasr sedool and Evisect. The last pesticide recorded the lowest reduction.

The above data, showed that Tregard, Reldan and Nasr sedool reduced the population of parasitoid $D$. isaea in moderate percentages with non significant differences.

In general, Evisect treatment gave the lowest reduction percentage on leaf minor Liriomyza trifolii and its parasitoid Diglyphus spp. Nasr sedool, Reldan and Tregard were responsible for high effects on $L$. trifolii and its prementioned parasitoid. Evisect gave higher effect against L. Trifolii than against Diglyphus isaea.

This results indicated that Evisect was the most safety insecticide among all used treatments on the parasitoid of L. Trifolii. (The active ingredient of Evisects, Thiocyclam hydrogen oxalate, is a derivative of mereistoxin, a naturally occurring insecticidal substance first isolated in 1934 from the marine annelid worm Lumbrinerels heterapoda).

Tregard was able to suppress L. Trifolii and promising compound for controlling it with a moderate effect on Diglyphus spp.
It could be concluded that the evaluation of insecticides by using the percentage of infested leaflets and counting the number of mines gave a quick estimation of its efficacy. However, counting the number of living larvae in the laboratory disply more accurate and reliable data.

\section{REFERENCES}

Abdalla, E.A. Abdallah, S.M. and Sammovr, E.A. (1992). Evaluation of certain insecticides for control of pea leaf miner Phytomyza atricornis (Meigen.) with notes about its significance. (African J. Agric. Sci., 44(2): 465-476).

Ahmed A. Barakat, Nadia Z. Dimetry, Hamdy E. El-Metwally (1994). Field evaluation of certain insecticides against the agromyzid Liriomyza trifolii (Burgess) attacking broad bean. (Bull. Ent. Soc. Egypt, Econ. Ser., 21:53-64).

Alverson, D.R. and Gorsuch, C.S.(1982). Evaluation of chrysanthemum cultivars and insecticides for control of damage by a leaf-miner, Liriomyza trifolii (Diptera, Agromyzidae). (J.Econ. Entomol.75: 888-891).

El-Haemeasy, A. H. Hammad, S.M., Zeid, M.I. and Tantawy, G. (1974). Control of the leaf-miner, Liriomyza trifolii (Burgess) on broad bean (Bull. Ent. Soc. Egypt, Econ. Ser., 8: 197-205).

El-Nahal, A.K.M. and Assem, M.A. (1970). The chemical control of the broad bean leaf-miner, Liriomyza trifolii (Burgess). (Bull. Ent. Soc. Egypt. Econ. Ser., 4: 205-217).

Hannou, M.A., S.F. Shweil, W.E. Khafagi and E.M. Hegazi (2000). Effects of a neem-based insecticide on populations of broad bean leaf-miner (Liriomyza spp.) and associated parasitoids in faba bean field. $1^{\text {st }}$ Int. Conf. Appl. Entomol., Cairo university. Faculty of Science.

Henderson, C.F. and E.W. Telton (1955). Tests with acaricides against the brown wheet mite J. Econ. Entomol., 48: 157-161.

Johnson, M.W., E.R. Oatman and J.A. Wyman (1980). Effects of insecticides on population of the vegetable leaf miner and associated parasites on fall pole tomatoes J. Econ. Ento., 73: 67-71.

Jones, V.P, M.P. Parrella and D.R. Hodel (1986). Biological control of leaf miners in green house chrysanthemum Calf. Agric., 40 (1 and 2): 10-12.

Parrella, M.P. and K.L. Robb. (1985). Economically important members of the genus Liriomyza Mik: a selected bibliography. Entomol. Soc. Am. Misc. Pub., 59.

Parrella, M.P., V.Jones and G.D. Christie (1987). Feasibility of parasites for biological control of Liriomyza trifolii (Diptera: Agromyzidae) on commercially grown chrysanthemum. Environ. Entomol. 16: 832-837.

Schuster, D.J. (1978). Vegetable leaf miners control on tomato, 1977 insectic acaric, tests 3:108.

Steel, R.G. and J.H. Torrie (1980). Principles and procedures of statistics a biometrical approach, 2ed Mc Grow-Hill Book Co., New York. 


\section{الملخص العربي}

\section{دراسة تأثير بعض المبيدات علي صانعات الأنفاق للأوراق(ذبابة الفاصوليا) والطفيل المرتبط بما}

\section{التي تصيب نباتات الفاصوليا في منطقة الإسكندرية}

ايفلين جودة إبراهيم، مني السيد عبد اللطيف، أحمد صبحي تاج بركات

بينما أعداد اليرقات الحية تعطي نتائج حقيقية لمدي الإصابة.

كذلك أطهرت النتائج أن مركب السيليكرون كان الأفضل دائما

لإنخفاض أعداد ذبابة الفاصوليا، أعطي مركب التريجارد نتائج مقبولة

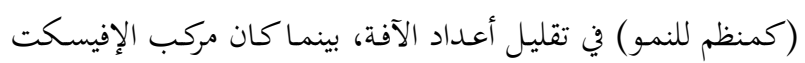

الأقل في نسبة الانخفاض لذبابة الفاصوليا وعلي عكس من ذلك لكن يعتبر

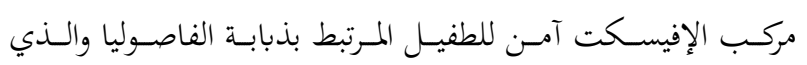

$$
\text { يستخدم في المكافحة الحيوية. }
$$

لذلك ينصح باستخدام التريجارد بدلا من السيلكرون كمركب آمن

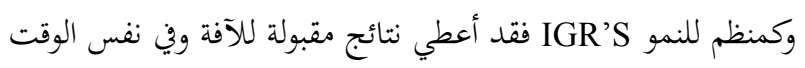

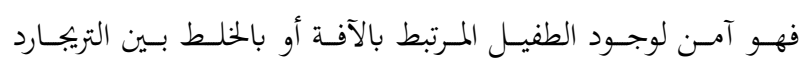

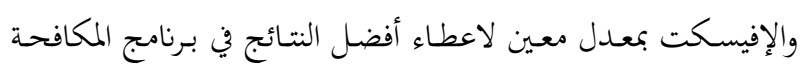

المـدف مـن البحـث هـو اختبـار كفــاءة خمس مبيـدات مختلفـة

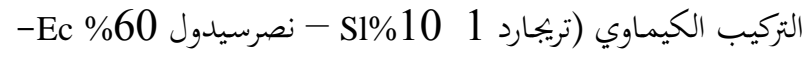

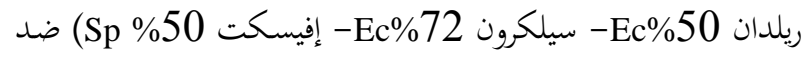

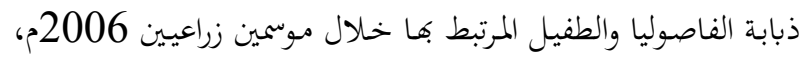

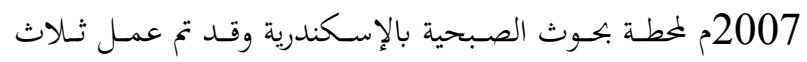

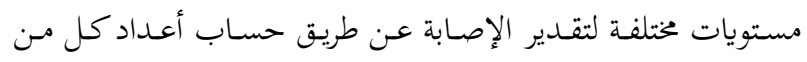

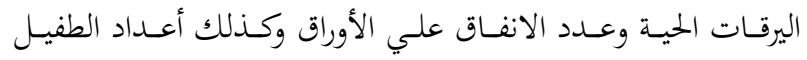

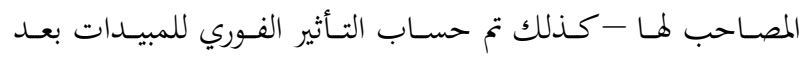
48ساعة من الرش وأيضا النسبة المئوية لمتوسط الانخفاض لكل منهم. وقد أظهرت النتائج أن أعداد الأنفاق لا تدل علي نسبة الإصابة الحقيقة فقد تكون خالية أو بها أعداد من اليرقات الميتة.

IPM. المتكاملة 